\title{
Corrigendum: The Emerging Role of Tetraspanins in the Proteolytic Processing of the Amyloid Precursor Protein
}

\author{
Lisa Seipold and Paul Saftig * \\ Institut für Biochemie, Christian-Albrechts Universität zu Kiel, Kiel, Germany
}

Keywords: tetraspanin, Alzheimer disease, membrane microdomains, amyloid precursor protein, secretases, amyloid beta

\section{OPEN ACCESS}

Edited and reviewed by:

Thomas Deller

Goethe-University, Germany

${ }^{*}$ Correspondence:

Paul Saftig

psaftig@biochem.uni-kiel.de

Received: 25 January 2017

Accepted: 31 January 2017

Published: 10 February 2017

Citation:

Seipold L and Saftig P (2017) Corrigendum: The Emerging Role of

Tetraspanins in the Proteolytic Processing of the Amyloid Precursor Protein. Front. Mol. Neurosci. 10:37.

doi: 10.3389/fnmol.2017.00037

\section{A corrigendum on}

The Emerging Role of Tetraspanins in the Proteolytic Processing of the Amyloid Precursor Protein

by Seipold, L., and Saftig, P. (2016). Front. Mol. Neurosci. 9:149. doi: 10.3389/fnmol.2016.00149

There was a mistake of a statement on page 5 (4th paragraph). It should read: “... In this regard downregulation of Tspan15, which predominantly promotes ADAM10-mediated N-cadherin shedding (Noy et al., 2016), by antagonistic mABs, sLELs, or RNAi, could be a therapeutic option....". The authors apologize for the mistake.

Conflict of Interest Statement: The authors declare that the research was conducted in the absence of any commercial or financial relationships that could be construed as a potential conflict of interest.

Copyright () 2017 Seipold and Saftig. This is an open-access article distributed under the terms of the Creative Commons Attribution License (CC BY). The use, distribution or reproduction in other forums is permitted, provided the original author(s) or licensor are credited and that the original publication in this journal is cited, in accordance with accepted academic practice. No use, distribution or reproduction is permitted which does not comply with these terms. 